Sreevidya Devanand

Gems Modern Academy

sreevidya.d1_mhs@gmesedu.com

\title{
The paradigm shift from books to graphic novels: The coherence and aesthetics of graphic narratives.
}

\begin{abstract}
This paper focuses on the seemingly important aspects of graphic novels that make them a remarkable genre of literature. The aesthetics and the power of illustration are taken into consideration in detail in the study. Maus by Art Spiegelman and Persepolis by Marjane Satrapi are taken as case studies. The radically different style used in Persepolis challenged the popular convictions on storytelling and its success as a graphic novel has profoundly influenced many Middle Eastern writers. To determine the efficacy of graphic novels, a survey is conducted among school students. Analysis is drawn from the survey and demonstrated with the help of graphs and pie charts.
\end{abstract}

Keywords: graphic novels, graphic narratives, storytelling

\section{Research Statement}

The paradigm shift from books to graphic novels - The coherence and aesthetics of graphic narratives.

\section{Research Question}

Is the sequential narration in graphic novels organized and filtered efficiently to interpret a complex text?

\section{Problem Statement}

For the past few decades, there has been a significant upsurge in the popularity of graphic novels among students, educators, and literary connoisseurs. The bright colored pages with panels in contrast colors, punch dialogues and successful blend of words and pictures have mass appeal among children and adults. Literary critics accept the artistic value of graphic novels. Educators embrace them as teaching materials. Schools and universities started adopting graphic novels as part of the curriculum. A group of writers, newspaper and magazine editors, librarians and academicians played a significant role in legitimizing comics and graphic novels into mainstream literature. The most intrepid, inventive, and imaginative stories about history, science and experiences of masses are depicted with utmost details in many graphic narratives. 'Logicomix: 
An epic search for truth' is an exceptional graphic novel that recounts the spiritual odyssey of the philosopher Bertrand Russe. Persepolis by Marjane Satrapi, a graphic iteration of her experience in Iran during the Islamic Revolution, marks an existential malady. Art Spiegelman's much-acclaimed graphic novel Maus, is an autobiographical memoir of his father's survival of Auschwitz. The book exposes the atrocities of the Holocaust with minuscule details about the life of prisoners in the concentration camp. Persepolis and Maus eventually became widely accepted symbols of revolution and dissent. This study focuses on how graphic novels hit language boundaries and narrate abstract subject matters ingeniously tangible.

\section{Introduction}

According to Leonardo da Vinci, a poet would be overcome by sleep and hunger before (being able to) describe with words what a painter can in an instant (Janson \& Janson, 2001). The tradition of narrative art dates to ancient Egypt, where events were recorded using sequential art and hieroglyphic symbols. He Done Her Wrong, a wordless graphic novel written by American Cartoonist Milt Gross, is a bona fide classic published in 1930. American artist Lynd Kendall Ward's God's Man: A Novel in Woodcuts was the first novel-length story told solely in pictures (Herb S, 2013). This work stands out not as a wordless book but as a story illustrated entirely in woodcuts. Graphic narratives, once considered juvenile, are now making a quantum leap in literary circles. This paper examines the merits of Graphic Novels and how to look at graphic narratives in cosmopolitan ways.

Several adaptations of classic literary works have been written in graphic form. Stefen Petrucha and Kody Chamberlain's version of Beowulf is an example. In the past graphic novels were dismissed as inferior literature. It was considered as a bridge that helps students to move to more serious literature eventually. Nevertheless, a person who reads a graphic novel must put more effort than one who reads a novel. They must examine, interpret, and understand the complex texts, decode them into various other elements like visuals, shading and composition, facial language and gestures of characters, and layout and representation. "Is the sequential narration in graphic novels organized and filtered efficiently to interpret a complex text?"

\section{Evolution of Graphic Novels}

A graphic novel is considered a euphemism for comics. However, a distinction between comics and graphic novels is challenging and ultimately irrelevant (vulture.com). In the 1970s, people with academic interest sought to validate the importance of comics by finding a lineage of word-image texts that evolved from cave paintings, Egyptian hieroglyphs and Mayan carvings of William Blake. The paintings in ancient Egyptian tombs record events through a combination of sequential drawings and hieroglyphic lettering. A monumental example of sequential art from the Roman period is Trajan's column completed in AD 113. Its spiralling carvings tell the story of the emperor Trajan's victory in the Dacian Wars. Similar narrative friezes are found on ancient Greek and Roman temples as well as early church buildings. Sequential art can also be seen in 
medieval tapestries, the most famous of which is the Bayeux's Tapestry (see Figure 1), recording the Norman invasion of Britain in 1066.

Figure 1:

Bayeux Tapestry: Battle of Hastings

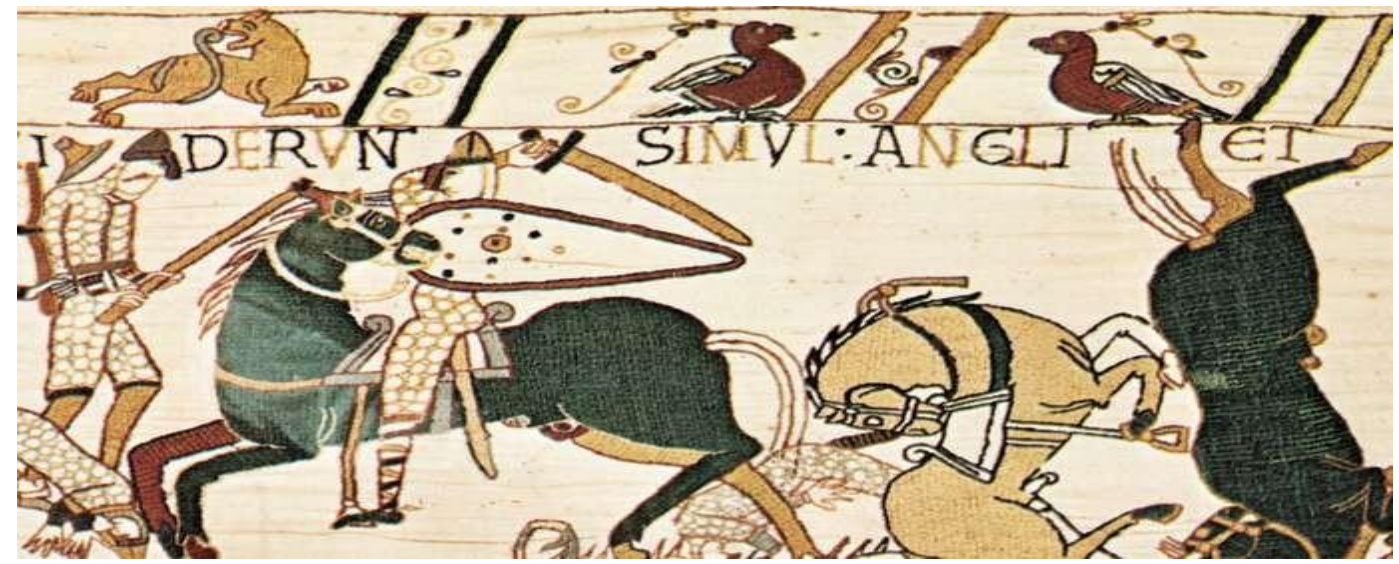

Note. From Encyclopedia Britannica. (www.britannica.com/topic/Bayeux-Tapestry)

Frans Masereel's Passionate Journey has played a pivotal role in the development of graphic novels. The story is a surrealistic expression of life crafted from 167 expressive black and white woodcuts without texts. The mastery of wood engraving is explicitly visible in each woodcut. The vivid and expressive images compress years of life in a few pages. Sometimes the powerful black-and-white images in light and shadow with long sequences narrate individual stories that create a hypnotic effect. From the first bustling frame to the last haunting image, the story unfolds through the readers' minds.

Figure 2

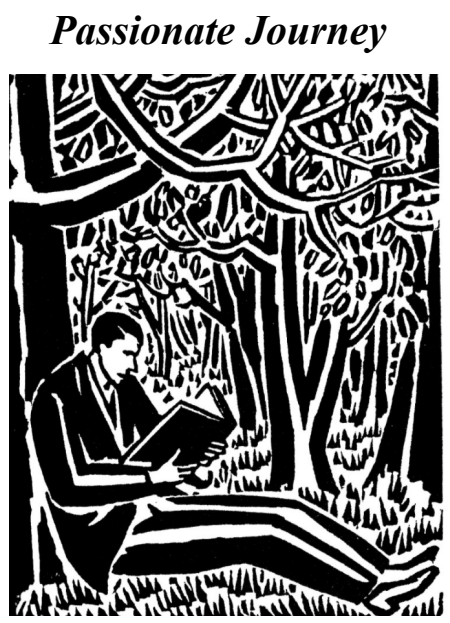

Figure 3

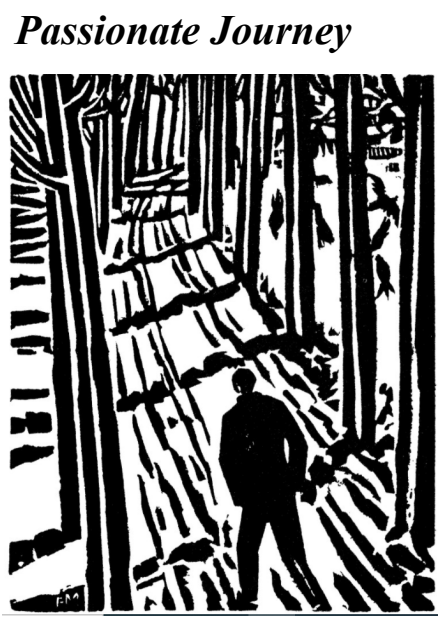

Note. From Caught by the River. (2012, December 20). www.caughtbytheriver.net/2019/03/the-gift-of-all-travel-frans-masereels-passionate-jour ney/ 
Debates are still going on about who coined the word graphic novel first. Scholars consider Will Eisner as the father of modern graphic novels for his much-acclaimed work, A Contract with God and Other Tenement Stories. There are many controversies associated with this. In his preface to A Contract with God, Eisner wrote that he was deeply influenced by Lynd Ward's woodcut novels, especially Frankenstein. The woodcut novels of Frans Masereel (1919), Flemish artist and the German artist Otto Nuckel (1930) are considered by scholars as the direct precursors of the modern graphic novel.

\section{Definitions}

According to Merriam-Webster, a graphic novel is a story that is presented in comic-strip format and published as a book (merriam-webster.com). Stephen Weiner defines a graphic novel as a book-length comic book. They are meant to be read as one story, including collections of stories in genres such as mystery, superhero or supernatural that are meant to be read apart from their corresponding ongoing comic book storyline (lib.umd.edu). In his work, Understanding Comics: The Invisible Art, American cartoonist Scott McCloud defines comics as "juxtaposed pictorial and other images in deliberate sequence" (McCloud, 1994).

\section{Literature Review}

One of the most argumentative concerns regarding graphic novels is their legitimacy. "A picture might be made from Shakespeare's description of the Cliff of Dover, but no picture could add to the sense that he awakens of its loftiness" (Congdon, 1884, p. 484). Comics establish an opportunity to practice metacognitive learning strategies because they spark autonomy so that the learners get involved in a variety of processes such as "planning, prioritizing, setting goals, and self-management" (Rubin, 1987). Half a century ago, psychologist Frederic Wertham testified to Congress that comic books contributed to juvenile delinquency (Springen, 2006). "The graphic novel's rise in popularity and sophistication has also grabbed the education community's attention. According to Gretchen Schwarz, graphic novels provide readers with the opportunity to learn about the literature they might otherwise never encounter" (Behler, 2006).

In his book Going Graphic, Anthony Pavlik mentioned the benefits of reading graphic novels, taking into consideration the stereotypes connected with graphic novels. There is a popular notion that graphic novels are not proper literature. According to him, narrative elements are treated differently with visual techniques. Combining graphic novel version and text-only version allows an extended reading experience. Harris (2006) identifies a decline in the dominance of exclusively text-based sources of information in modern society. He challenges those involved in information literacy education to address the situation thoughtfully.

The reality of the current information economy is that images are in higher circulation and higher demand than words and print. This should not suggest that we create an opposing hierarchy 
where images rule words but understanding the shifting relationship between word and image at this juncture in information literacy theory is imperative. While few have questioned that verbal and alphabetic literacies must be learned, a lack of sensitivity to (or fear of) images and visual texts has obscured the need for instruction in reading images. As images become ever-present in the communication of information between entities, communities, and individuals, librarians and related professionals must consider the visual in any discussion of information literacy (Hoover, 2012).

Hansen (2012) mentioned that many teachers reported great success with graphic novels in classrooms and tells that:

Maureen Bakis joyfully recounts the skills that graphic novels helped foster in her students: Using graphic novels allowed students to think critically and analytically, and because the graphic novels we read elicited sophisticated and mature discussion about topics that mattered to them, they were able to develop a different personal style, voice, and other aspects of their writing. Because they developed a passion for the stories and a genuine appreciation and understanding of the artistry of the comics they were reading, students were more engaged toward in-depth discussions (p. 61).

According to Roland Barthes, stories can be told in all media. Today graphic narratives have become ubiquitous both in quantitative and qualitative terms. They are increasingly accepted as a culturally valuable form of storytelling (Baetens, 2018).

Mary Rice, a junior high school teacher, mentioned in one of her articles that her experience while reading American Born Chinese changed her perception of graphic novels. She mentions in her work that interpreting the text and making connections with the visuals was not an easy task (Rice, 2012). Gord Downie's album based on a graphic novel, The Secret Path, is a classic blend of animation, music and illustrations. The three mediums synchronized together have a breathtaking impact on the viewer (Downie, 2016). This wordless graphic novel evokes the subtlety of illustrations allowing the reader to empathize and relate to the character depicted in the story. Graphic novels like Barefoot Gen, Palestine, Safe Area Gorazde, and Persepolis, feature complex themes on war and its atrocities, current political realities, and coming-of-age in a time of revolution. They can be part of what Benesch (1993) called "a critical ESL curriculum" (p. 714). Cross-modal critical analysis can then occur; for example, students can compare these graphic novel perspectives on historical realities with other views presented by film documentaries, Wikipedia entries, and textbooks. Teaching Maus in the secondary school classroom can employ a critical multiliteracy approach to affirm students' identities as thinkers and learners. Cromer and Clark (2007) at the University of British Columbia talk about the intertextuality of graphic novels. They quote Walter Werner (2004) in his paper titled Getting Graphic with the Past: Graphic Novels and the Teaching of History. 
According to Walter Werner, whenever a pictorial image is read in terms of or alongside another image or a surrounding set of images and words, intertextuality is at work and meanings assigned to the image differ from those that would be drawn if it were interpreted in isolation (pp. 64-65). Patricia Storace (2005), in her review of the graphic novel Persepolis, says, "Either element would be quite useless without the other; like a pair of dancing partners, Satrapi's text and images comment on each other, enhance each other, challenge, question, and reveal each other" (para. 2). Lavin (1998) noted that students who read graphic novels use more cognitive thinking skills during reading than when they read more traditional novels. Additionally, the multimodal nature of this format may help students navigate complex ideas in content areas and improve comprehension. Lyga and Lyga (2004) state, "Even students whose reading abilities deter them from enjoying reading for the inherent satisfaction are drawn to graphic novels" (p. 56). Many teachers hope to foster motivation and engagement for young readers, using graphic novels in the classroom to fill the void that some students seem to have when reading. An educator, who offered graphic novels in book groups in a middle school elective class who found that students were adept at reading those texts, stated that "the jokes, the conclusions, and the characters made sense at once" (Seyfried, 2008, p. 46) to the students.

The studies detailed above shed light on the positive effects of reading graphic novels and the popular notions. The subject matter, length of the story and its depiction, the interplay of text and images, and its coherence in treating a complex subject make The facial expressions, the colour, the body language, the boxes, and the speech bubbles all contribute to the success of a graphic novel. The fundamental question that should be asked is, can graphic novels be treated as seriously as traditional novels? Can it create a psychological effect on the reader while treating a complex subject? Is one picture worth ten thousand words?

\section{Methodology}

The study used mixed methods to collect qualitative and quantitative data to understand the research problem and get more insight into the merits of graphic novels. The purpose of this study was to ascertain the quality of graphic novels in treating complex topics. The study also included different aspects and the techniques used in graphic novels that make it different from other media. A survey was conducted among students and academics to determine the aesthetics of graphic novels instead of traditional full-text novels. Art Spiegelman's autobiographical memoir on the Holocaust and Marjane Satrapi's childhood experiences of her life during the Islamic revolution are taken as case studies. The study focused and explored the meaning-generating mechanisms used in both books by their authors.

\section{Maus: Remembering Holocaust through comic representation}

With the onset of The Great Depression following World War 1 Nazis came to power. The extremist right-wing political party sponsored the execution of Jews as they believed that Jews were an inferior race and might become a threat to the racial superiority of Germans. The 
solution that Hitler came up with is the extermination of Jews, which came to be known in history as the Holocaust. The word Holocaust is used to describe a sacrificial offering burned on an altar. Six million Jews were massacred in Holocaust during their regime (ushmm.org). Many groups other than Jews were targeted too based on racial and political prejudices. The physically and mentally disabled, the Poles and other Slavic people were also victims of the brutal genocide. Today, we remember Holocaust through the enormous amount of Holocaust literature, monuments and museums, drawings and photographs by the victims and the cataclysmic memories of the survivors about their life in the concentration camps. Many veterans who were eye-witnesses to the Holocaust made significant commitment to uplift the life of Holocaust survivors.

However, a paradox of trauma is that emotions cannot be conveyed precisely as felt by the victims. Comics often represent funny stories and Holocaust is anything but funny. So, any attempt to express the horrors of the genocide (which remains a touchstone of trauma) could evoke a question on analyzing its historicity and truthfulness. Numerous writers have written about the Holocaust. Nevertheless, while representing such an event in graphic form, a question arises: will some inaccuracies make the story deviate from the truth as told by the survivors? How is the gap between truth and imagination bridged?

In Maus: A Survivor's Tale, famous cartoonist and illustrator Art Spiegelman illuminates vivid memories of the Holocaust and attempts to analyze the trans-generational trauma of the second generation (Burza, 2021). His graphic memoir is told in three levels of time: the survival of Vladek in Auschwitz, the interview that describes his memories and Spiegelman's reflection on the events after his father's death from which he wrote his second book. The connection between the past and the present is poignant throughout the story. Maus has not lost the charm of narrative power even after thirty years of its publication. The work is considered one of the most significant artistic victories of the 20th century (libraries.mit.edu). Nonetheless, controversies still exist regarding the anthropomorphic representation of the characters. Abstract images help to make connections with a wider world and detect incongruities and absurdities. Spiegelman uses these characters to throw light on his own life and the effect of Holocaust on him. He gives an account of the brutalities without narrating it explicitly. The use of the cat-and-mouse metaphor escapes the moral responsibility of killing since cats' kill mice and they leave the dead mice for their masters. Perpetrators of the Holocaust were torturing and killing the victims for Hitler. In an interview given to the BBC, Spiegelman recounts that the cats and mice heads are masks that the characters are wearing. In one of his interviews, Spiegelman mentions the use of cat-and-mouse metaphor in his work.

\section{An excerpt from the interview}

Ultimately, what the book is about is the commonality of human beings. It is crazy to divide things down nationalistic or racial or religious lines. These 
metaphors, which are meant to self-destruct in my book-and I think they do self-destruct-still have a residual force that allows them to work as metaphors, and still get people worked up over them (Spiegelman, 1991).

To compare a written account of the Holocaust and a graphic representation which treats almost the same situation let us take the examples given below in Figures 4 and 5. Both describe a day of the victim in Auschwitz.

The testimony:

"you run to join your work team. You will leave the camp under the heavy guard of SS and kapos, always barking at you. You will reach the yard by walking of course. Maybe you will have to march off to the beat of the music played by the camp orchestra. Or maybe the SS will order your work team to sing during the march. Just at the gate of the camp, there is a row of SS waiting for your work team. Beatings, insults, barking again and again...(jewishgen.org)."

Figure 4

Everywhere was confusion

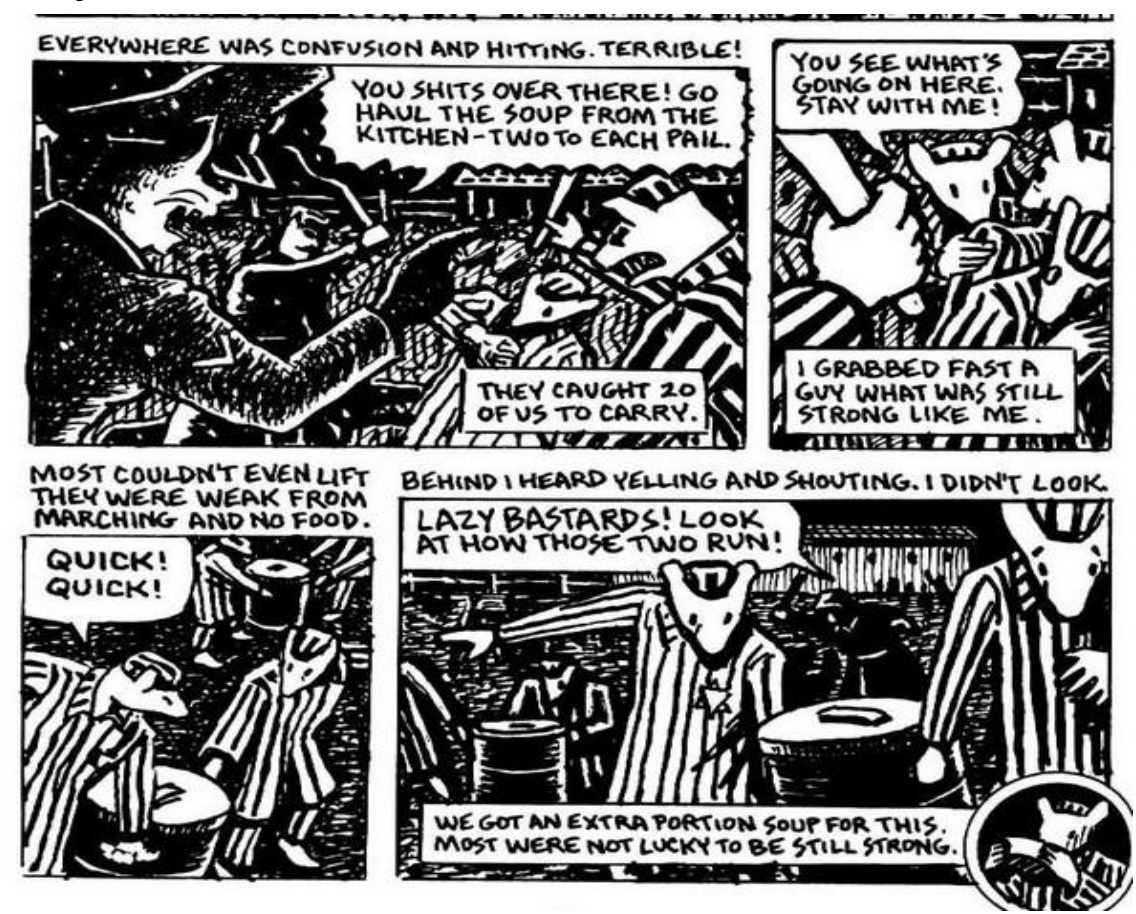

Note. From. McCloud, S. (1994). Understanding comics. New York: Harper Perennial.

Both text and graphic form narrates the horrors of the concentration camp and displays the devastating experiences of the inmates. However, the graphic panel ingeniously makes the story come alive with its visual and textual forms. Pictures and words in black and white add different connotations to the situations portrayed. The style of narration and the shadings provides a new way to perceive the atrocities of the Holocaust without traumatizing the readers. 


\section{Figure 5}

\section{Towards the direction of Sosnowiec}

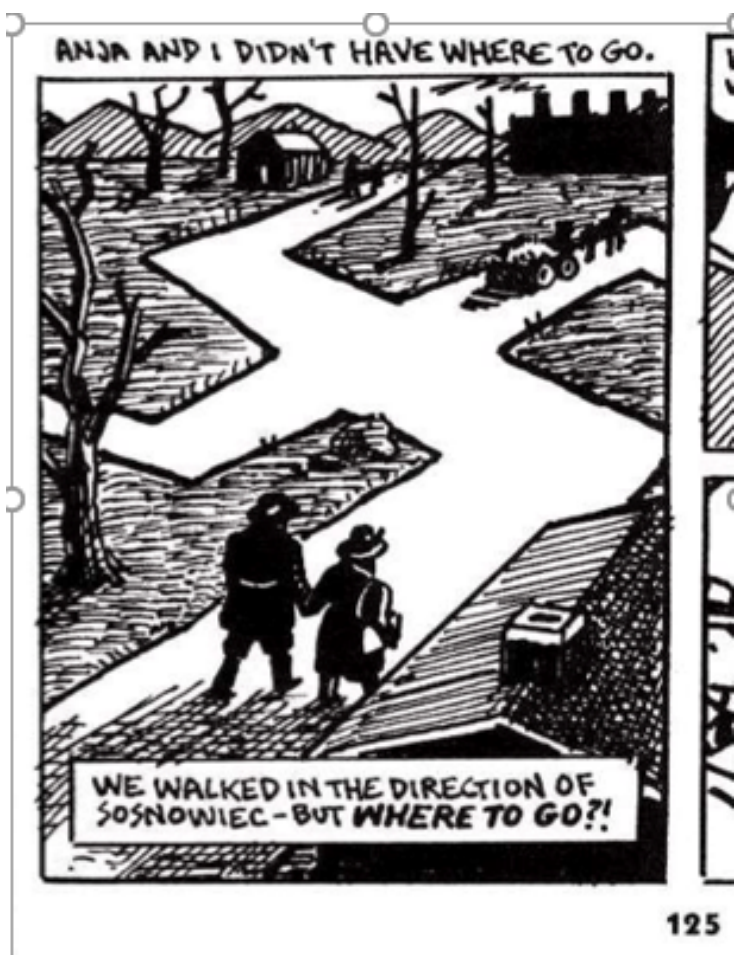

Note. From McCloud, S. (1994). Understanding comics. New York: Harper Perennial

In Figure. 5, from page 127 of The Complete Maus, Vladik and Anja walk through a place somewhat similar to a park after leaving the ghetto. The narrative panel says that they were walking in the direction of Sosnowiec but were not sure where to go. The panel has simplicity and charm of its own. However, simultaneously it shows the relentless horror of the Nazi camp. There are no hiding places around except for a few houses. The leaves of the trees are withered and the path they were walking is drawn in the shape of a swastika which explicitly says why they have nowhere to go. No matter where they try to escape, they will be caught by the Nazis. The stark black and white shades and the zigzag lines of the path in the shape of swastika amplify the enormity of the horror imposed by the Holocaust.

With the enormous of account on Holocaust literature, people are aware of the brutal massacre, the horrors of the gas chamber and humanbeings shovelled into ovens. However, the animal allegory and the diagrams Spiegelman uses are entirely different experiences for the readers to visualize life in the concentration camps. The subtle representation of the characters are detailed to provide a more fabulous room for interpretation and perception from the readers. The readers themselves become a part of the world described in the story to an entirely higher level of experience. 


\section{Persepolis: The story of a childhood.}

Persepolis is a graphic memoir by Marjane Satrapi that describes her distinct childhood experience in Iran during and after the Islamic revolution. The story chronicles Satrapi's life under the oppressive Iranian regime and the restrictions imposed on Iranian women under the rule of the spiritual leader Ayatollah Khomeini. The graphic novel illustrates how women and children were excluded and marginalized during the revolution. Through the unique blending of history and personal experiences, she depicts her struggle against the dictatorship. The stark black and white panels with elegant details expose the bewildering contradictions in her journey from childhood to adulthood and the conflicts and inconsistencies of a life that is forced upon her. The visual symbolism in the novel brilliantly portrays the coming of age problems of a teenager and the concerns and challenges of adulthood. The panels on many pages outweigh the power of language. Most of the frames can be interpreted well without their corresponding text with the careful optimization of the graphic elements in the novel.

\section{Figure 6}

\section{The veil: symbol of oppression}

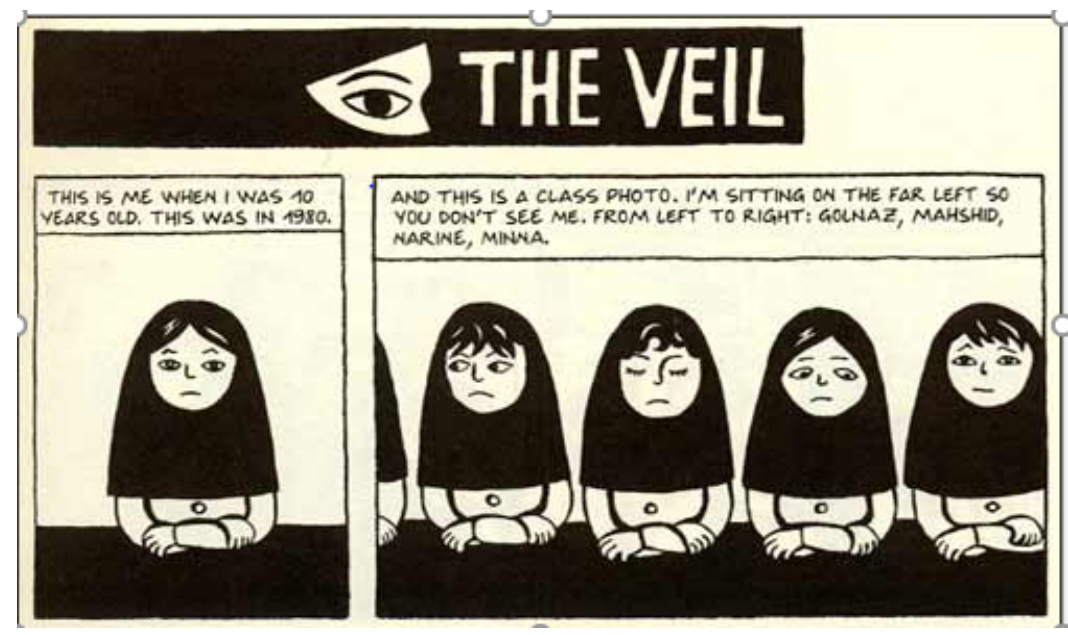

Note. From Satrapi, M. (2007). The complete Persepolis. New York: Pantheon Books.

In Persepolis, Satrapi uses the veil (which became obligatory for all women to wear) as the symbol of oppression. The story exposes "her transition from her state of conformity, to her metaphorical unveiling of the truth behind the Islamic regime and ultimately her complete rebellion that leads to her eventual freedom" (Anderson, 2018). On the opening page, she portrays herself and a group of girls forced to wear the veil due to the newly enforced rules. This is one of the most striking images of Satrapi in the novel, which talks a lot about her in the rest of the story. Her eyes are set directly at the reader with hands folded like a prisoner who is shut off from the world. She deliberately cuts her off from the right panel to show that all the girls look the same with the veil on, and they all appear so insignificant that there will not be any difference whether she is in the picture or not (Anderson, 2018). 


\section{Figure 7}

\section{The divided self}

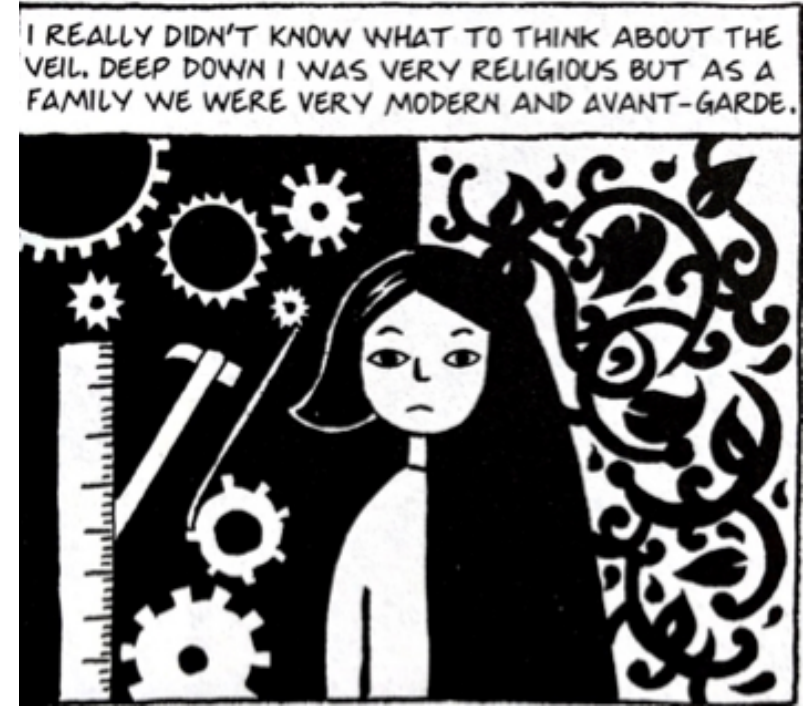

Note. From Satrapi, M. (2007). The complete Persepolis. New York: Pantheon Books

The above panel in Figure 7 shows the confused Satrapi in the middle of two contradictory backgrounds, emphasizing her emotions. She uses the comic artist Scott McCloud's theory about communicating the invisible ideas and emotions of the character through backgrounds. This panel expresses opposition between the left and right sides representing the modern and religious worlds, respectively. This illustrates Satrapi's actual self (the girl with the veil on) and her ideal self (without the veil).

In Persepolis, countless social and cultural issues that existed at the time of political unrest and tyranny are addressed. Some of the panels are a perfect blend of verbal narration and visual storytelling. The image given below in Figure 8 is one example.

\section{Figure 8}

\section{Struggle for freedom}

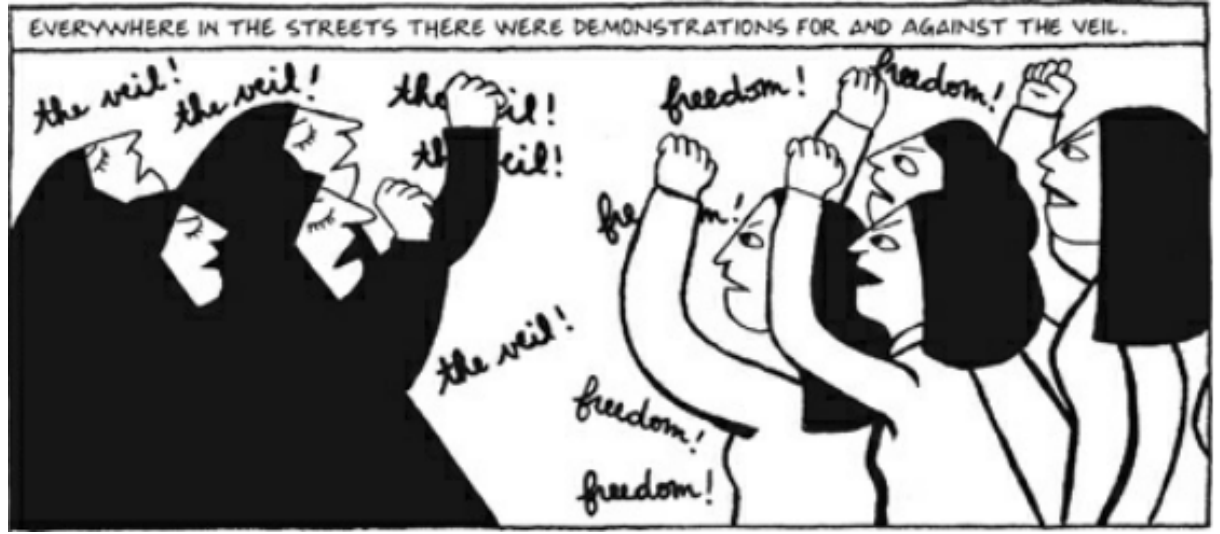

Note. From Satrapi, M. (2007). The complete Persepolis. New York: Pantheon Books 
In Figure 8, the narrative panel says that there are demonstrations for and against the veil everywhere in the streets. Below the narrative panel are two groups of women with subdued facial expressions. They are pretty much different in their opinion about the veil. The women on the left panel favor the veil, while the other group is against the veil. The women who are not ready to wear the veil (which is Satrapi's view) are pictured at the right side of the panel. The women whom she thinks are right are placed on the right side. Simultaneously the color portrayal is well suited to express their views and ideologies. The women who are in favor of the veil are drawn in black, and those who chose freedom are in white. The color black is often associated with something depressing and sometimes portrays villains. In this image, she is trying to show her stance on the repression of women and the rules imposed on them during the revolution. The images on the right panel are drawn with open eyes, staring at their opponents, while those on the left side are drawn with eyes shut.

With their eyes closed, the women blindly follow the laws imposed on them or helplessly adhere to their religious practices. Ultimately in a single panel, the author brilliantly depicts multiple emotions through facial expressions, color contrasts and juxtaposed images. The panels move forward in time with the successful blending of verbal and visual narratives. The shades of reality are beautifully conveyed with well-framed thoughts in panels, gutters and speech bubbles. Each page reflects Marjane's inner conflicts and struggles. The indescribable pain of her childhood becomes our pain, conflicts and struggles. Faces and panels take the readers across time, space and memory. As Scott McCloud puts it, the universality of a cartoon image is that we see ourselves when we enter the cartoon world. We do not just observe the cartoon; we become it (oliviachadha.com).

\section{Findings}

An online survey was conducted among students and academics to determine the legitimacy of graphic novels. The results from the survey revealed that students tend to have a positive approach towards reading graphic novels. $97 \%$ of the respondents favoured graphic novels. According to the survey results, Maus and Persepolis are the most read graphic novels. $95 \%$ of the participants perceive that visual representation helps connect with the characters, and a specific focus on human relationships makes graphic novels more effective. Of the 68 participants who received the survey, $97 \%$ enjoy reading graphic novels, and $92 \%$ think that complex ideas can be depicted effectively through graphic narratives.

\section{Discussion and Implication}

Graphic novels have changed considerably in recent years. The medium is introduced into mainstream literature, and academics have integrated graphic novels like Maus and Persepolis into classrooms. The reading habits of students have also changed in recent years. Studies have shown that a well-executed graphic novel is reader-centric, unlike in standard text, where the story focuses on the author's perspective. This implies that a skilled writer can bring out the best 
elements more precisely without distracting the reader's attention. Illustration in graphic novels helps to better understand the story in a sequence where emotions are stored for a long time in the subconscious mind.

\section{Conclusion}

"Language originated with visuals - real things used as signs or visual gestures...language was metaphoric, imagistic, and poetic from its inception" (Phelps, 2011, p. 8.). Graphic novels richly deserve attention and praise for their remarkable capability for blending text and graphics. They have the intensity to inspire readers to find their voice. Visual representation triggers emotions. The stylistic techniques used in graphic novels like Maus and Persepolis emphasizes the subtleties of human relationships without distracting the reader from the story. Panels festooned with images and backgrounds entice the readers into the plot without interrupting their thoughts. While moving forward with the story, the reader goes through a creative mode and interprets the character according to individual perceptions. When details are delicately infused with text and images, graphic novels give an otherwise impossible insight into a particular situation, unlocking memories, reflecting on a current scenario or lucidly engaging a reluctant reader. It transcends imagination by giving a rapport to reality instead of the idealistic notion of life. In times of disquiet and political correctness, where facts and history are oversimplified and forgotten, graphic novels articulate events and personal experiences from a different perspective. By combining the most remarkable aspects of art and literature, graphic novels are undoubtedly an outstanding compendium of both.

\section{References}

Anderson, C. (2018, March 19). Exploring the significance of the veil in Marjane Satrapi's "Persepolis". Retrieved March 12, 2021, from medium.com/@camillaanderson/exploring-the-significance-of-the-veil-in-marjane-satrap is-persepolis-416886a817e4

(n.d.). Retrieved January 20, 2021, from www.jewishgen.org/ForgottenCamps/Camps/MainCampsEng.html

Baetens, J. (2018). Stories and storytelling in the era of graphic narrative. In Christie I. \& Van den Oever A. (Eds.), Stories (pp. 27-44). Amsterdam: Amsterdam University Press. doi:10.2307/j.ctv5rf6vf.6

Banks, D. W. (n.d.). Awakening Voice and Facilitating Healing: Exploring Maus, Persepolis and the Power of Graphic Memoir. Retrieved September 7, 2020, from www.academia.edu/45587051/

Encyclopedia Britannica. Bayeux Tapestry: medieval embroidery [graphic]. Britannica. www.britannica.com/topic/Bayeux-Tapestry

Behler, A. (2006). Getting started with graphic novels: A guide for the beginner. Reference \& User Services Quarterly, 46(2), 16-21. Retrieved January 17, 2020. 
Books, A. (2015, November 10). Will Eisner and the Secret History of the Graphic Novel. Retrieved from www.vulture.com/2015/10/will-eisner-graphic-novels-paul-levitz.html

Boston University Arts \& Sciences Writing Program. (n.d.). Retrieved April 6, 2021, from www.bu.edu/writingprogram/journal/issue-11/chen/

Burza, M. (2021). From Wounds to Graphics: The Representation of Holocaust Trauma in Art Spiegelman's Maus. Strife. Retrieved September 28, 2020, from www.strifeblog.org/2021/04/15/from-wounds-to-graphics-the-representation-of-holocaust -trauma-in-art-spiegelmans-maus/

Chun, C. (2009). Critical literacies and graphic novels for English-language learners: Teaching Maus. Journal of Adolescent \& Adult Literacy, 53(2), 144-153. Retrieved June 28, 2021, from www.jstor.org/stable/40344359

Comics \& Graphic Novels Memoir Course. (n.d.). Retrieved June 3, 2021, from www.oliviachadha.com/graphic-memoir-comics

Congdon, C. (1884). Over-Illustration. The North American Review, 139(336), 480-491. Retrieved January 27, 2020, from www.jstor.org/stable/25118436

Cromer, M. \& Clark, P. (2007). Getting graphic with the past: Graphic novels and the teaching of history. Theory \& Research in Social Education, 35(4), 574-591. https://doi.org/10.1080/00933104.2007.10473351

Downie, G. (2016, October 18). The Secret Path. Retrieved January 20, 2020, from www.youtube.com/watch? $v=y G d 764 Y U 9 y c$.

Graphic Novels \& Comics: What Is a Graphic Novel? (n.d.). Retrieved November 28, 2020, from lib.guides.umd.edu/comics

Hansen, K. S. (2012). In defense of graphic novels. English Journal, 102(2), 57-63.

Jennings, K. A. (2014). Fifth Graders' Enjoyment, Interest, and Comprehension of Graphic Novels Compared to Heavily-Illustrated and Traditional Novels [Pdf]. Iowa: University of Northern Iowa.

Masereel, F. (1919). [Graphics from Passionate Journey]. Caught by the River. (2012, December 20). Retrieved from www.caughtbytheriver.net/2019/03/the-gift-of-all-travel-frans-masereels-passionate-journ ey/

McCloud, S. (1994). Understanding comics. New York: Harper Perennial.

Merriam-Webster. (n.d.). Graphic Novel. Retrieved from https://www.merriam-webster.com/dictionary/graphic novel

Murray, C. (n.d.). The First Graphic Novels. Britannica. Retrieved from www.britannica.com/art/graphic-novel/The-first-graphic-novels

Öz, H., \& Efecioğlu, E. (2015). Graphic novels: An alternative approach to teach English as a foreign language. Journal of Language and Linguistic Studies, 11(1), 75-90

Phelps, V. L. (2011). Pedagogy of Graphic Novels (Unpublished master's thesis). Western Kentucky University. Retrieved May 1, 2021, from https://digitalcommons.wku.edu/ 
Rice, M. (2012). Using graphic texts in secondary classrooms: A tale of endurance. The English Journal, 101(5), 37-43. Retrieved April 1, 2021, from www.jstor.org/stable/23269526

Satrapi, M. (2007). The complete Persepolis. New York: Pantheon Books.

Seyfried, J. (2008). Reinventing the book club: Graphic novels as educational heavyweights. Knowledge Quest, 36(3), 44-48.

Springen, K. (2010, March 14). Libraries: Graphic-novel idea. Retrieved January 15, 2020, from www.newsweek.com/libraries-graphic-novel-idea-110087

Steven, H. (2012). The case for graphic novels. University of Nevada.

Storace, P. (2005). A Fearless Graphic Memoir: On Marjane Satrapi's Persepolis. The New York Review of Books. https://bookmarks.reviews/a-fearless-graphic-memoir/ 


\section{Survey Questionnaire and Responses}

\section{Appendix A}

Are you

68 responses

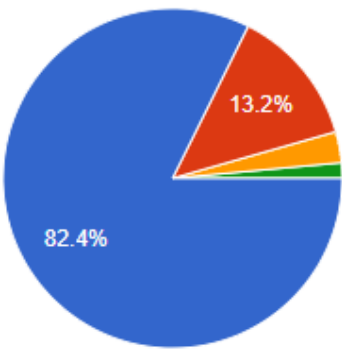

$$
\begin{aligned}
& \text { Student } \\
& \text { Educator } \\
& \text { Odhers } \\
& \text { Educationalist }
\end{aligned}
$$

Can you name one of the graphic novels you have read?

68 responses

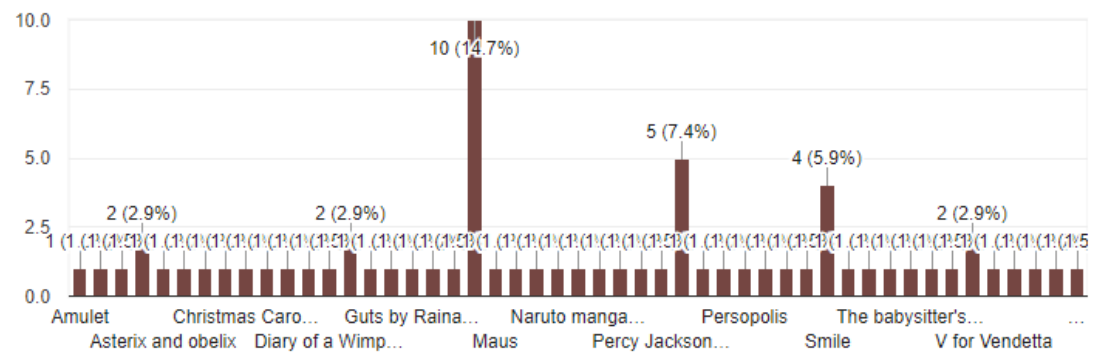

Did you enjoy reading it?

68 responses

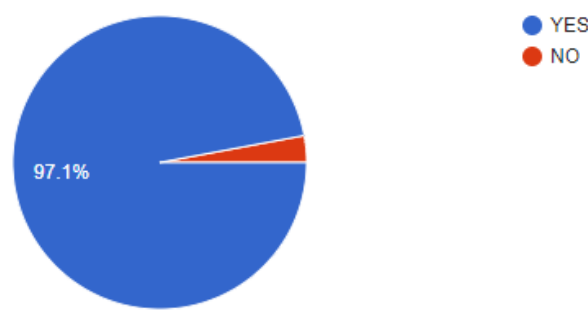




\section{Appendix B}

What was your experience in reading the graphic novel?

68 responses

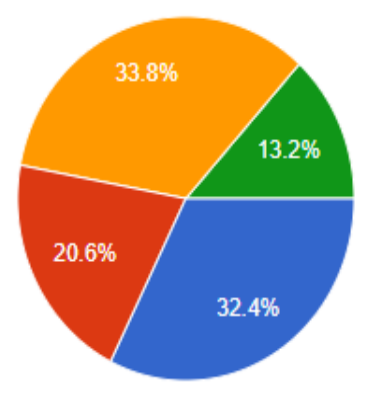

Thought provoking

Exciting

Visually impressive

Funny

Did the visual representation of the characters justify the story depicted? 68 responses

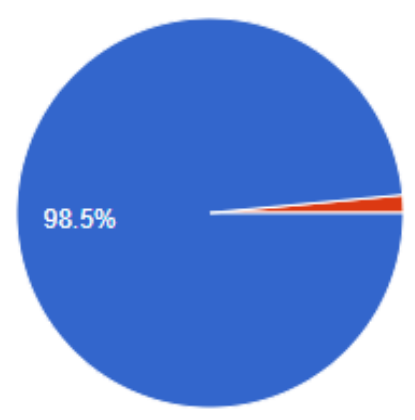

YES

NO

Was the plot rich enough to evoke your imagination?

68 responses

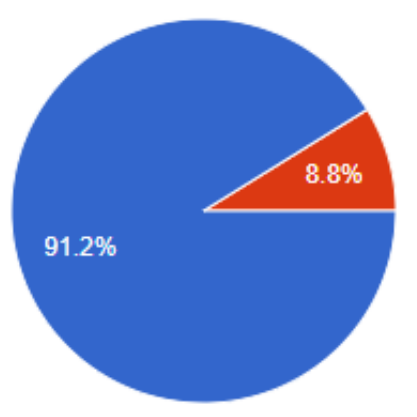

YES

NO 


\section{Appendix C}

Has the author focused on the emotions and feelings of the character or is it more attuned to the plot described in the story?

68 responses

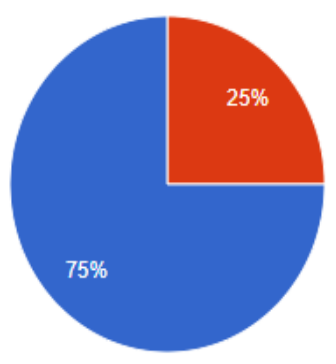

Focused on the emotions and feelings

More attuned to the plot described

Given the same story in book format would you prefer graphic novel or book? 68 responses

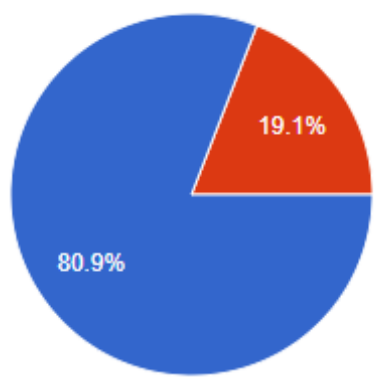

Graphic Novel

Book

Did the visual image in graphic novels succeed in recounting the characters in depth?

68 responses

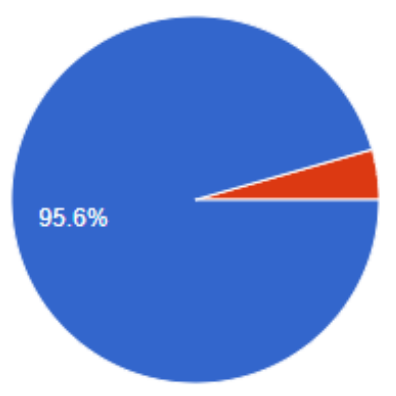

Yes

No 


\section{Appendix D}

Did you feel the pattern has an impact on the story?

68 responses

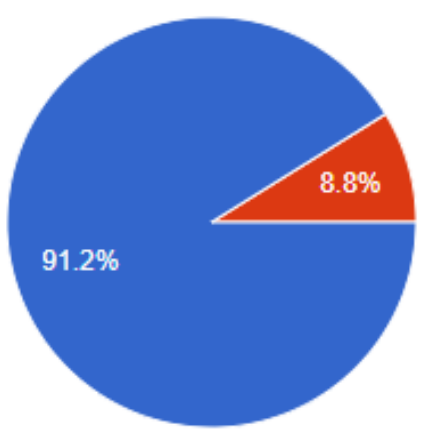

Yes

No

Do you think complex ideas can be depicted through graphic narrative 68 responses

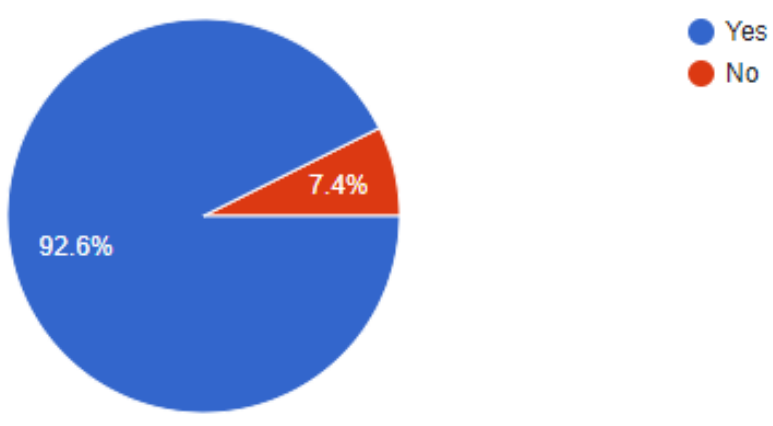

